\begin{tabular}{l|l}
\hline Totaice & $\begin{array}{l}\text { e-ISSN: 2655-9404 p-ISSN: 2721-8376 } \\
\text { DOI: } 10.20473 / \text { ntr.v5i1.33639 }\end{array}$ \\
Vol. 5 No. 1, Februari 2022 &
\end{tabular}

Article history: Submitted 13 February 2022; Accepted 18 February 2022; Available online 24 February 2022.

\title{
Kedudukan Objek Sewa Guna Usaha Dengan Hak Opsi (Finance Lease) Dalam Kepailitan Lessee
}

\author{
Risma Cahya Yudita Pratama dan M. Hadi Shubhan \\ risma.cahya.yudita-2019@fh.unair.ac.id \\ Universitas Airlangga
}

\begin{abstract}
Finance lease is a form of lease agreement for a certain period of time with payments in installments and at the end of the agreement the lessee has the right to purchase the previously leased goods or continue the lease agreement. In the case of a lessee's bankruptcy, all the assets of the bankrupt debtor will become the bankruptcy estate and what was obtained during the bankruptcy. The bankruptcy resulted in the implementation of the lease agreement being unresolved and the position of the object of the lease being unclear. The existence of this ambiguity is important to be discussed further because it becomes the basis for legal protection for the lessor in which the lessee is declared bankrupt while the agreement is still in progress. Through the statute approach, conceptual approach, and case approach, it is concluded that the continuation of the implementation of the lease agreement with option rights will be stopped if the curator does not provide an answer or refuses to continue the agreement but if the curator is willing, then the agreement will continue with guarantees. at the discretion of the curator. Regarding the object of the lease, the lessee will become bankruptcy boedel because the rights born from the lease agreement are individual rights, where these rights only have relative legal power.

Keywords: Leasing; Finance Lease; Lessee; Leasing Object; Bankruptcy; Bankrupcty Boedel.
\end{abstract}

\begin{abstract}
Abstrak
Sewa guna usaha dengan hak opsi (finance lease) merupakan bentuk perjanjian sewa guna usaha selama jangka waktu tertentu dengan pembayaran secara angsuran dan pada akhir masa perjanjian pihak penyewa guna usaha memiliki hak untuk membeli barang yang telah disewa sebelumnya atau melanjutkan perjanjian sewa guna usaha. Dalam kasus kepailitan lessee, maka segala harta kekayaan debitor pailit akan menjadi harta kepailitan dan apa yang diperoleh selama kepailitan. Kepailitan tersebut mengakibatkan pelaksanaan perjanjian sewa guna usaha yang belum terselesaikan dan kedudukan objek sewa guna usaha menjadi tidak ada kejelasan. Adanya ketidakjelasan tersebut menjadi penting untuk dibahas lebih lanjut karena menjadi dasar bagi perlindungan hukum terhadap lessor yang dimana pihak lessee dinyatakan pailit pada saat perjanjian masih berlangsung. Melalui pendekatan perundang-undangan, pendekatan konseptual, dan pendekatan kasus maka diperoleh kesimpulan bahwa kelanjutan pelaksanaan perjanjian sewa guna usaha dengan hak opsi yang akan menjadi terhenti apabila kurator tidak memberikan jawaban atau menolak untuk melanjutkan perjanjian tetapi apabila kurator bersedia, maka perjanjian akan berlanjut dengan jaminan atas kesanggupan oleh kurator. Terkait objek sewa guna usaha akan menjadi boedel pailit lessee karena hak yang lahir dari perjanjian sewa guna usaha adalah hak perorangan, dimana hak tersebut hanya berkekuataan hukum relatif.
\end{abstract}

Kata Kunci: Sewa Guna Usaha; Hak Opsi; Penyewa Guna Usaha; Objek Sewa Guna Usaha; Kepailitan; Harta Pailit. 


\section{Pendahuluan}

Perekonomian Indonesia di era globalisasi saat ini sedang mengalami perkembangan yang pesat. Selain lembaga perbankan yang menjadi penunjang perekonomian masyarakat, meningkatnya kesejahteraan perekonomian masyarakat juga tidak terlepas dari peran serta pihak Lembaga Keuangan Bukan Bank, baik secara langsung maupun tidak langsung dapat dilihat dari peningkatan kegiatan di bidang pembiayaan selain dengan adanya lembaga perbankan. ${ }^{1}$

Sewa guna usaha sesuai Pasal 1 angka 5 Perpres No. 9 Tahun 2009 adalah kegiatan pembiayaan dalam bentuk penyediaan barang modal baik dengan hak opsi (finance lease) maupun tanpa hak opsi (operating lease). Aturan terkait sewa guna usaha tidak terdapat dalam Burgerlijk Wetboek (selanjutnya disebut BW), tetapi karena Buku III BW menerapkan sistem terbuka atau open system, para pihak dapat membuat perjanjian sesuai dengan kesepakatan walaupun yang tidak diatur secara khusus dalam BW. ${ }^{2}$ Buku III BW hanya sekedar mengatur dan melengkapi (regelend recht-aanvullendrecht). ${ }^{3}$

Kreditor dapat meminta pertanggung jawaban hukum terhadap debitor yang tidak dapat memenuhi kewajibannya sesuai dengan kesepakatan dalam perjanjian. ${ }^{4}$ Salah satu cara yang dapat ditempuh baik oleh debitor maupun kreditor untuk menyelesaikan permasalahan tersebut adalah dengan mengajukan gugatan kepailitan ke Pengadilan Niaga.

Harta kekayaan milik debitor pailit akan menjadi jaminan bersama terhadap para kreditor dan dibagi dalam jumlah yang proporsional diantara para kreditor, kecuali di antara para kreditor ada yang menurut undang-undang harus didahulukan dalam hal pembayaran, sesuai dengan prinsip pari passu pro

${ }^{1}$ Amin Widjaja Tunggal and Arif Djohan Tunggal, Aspek Yuridis Dalam Leasing (Rineka Cipta 1994).[1].

${ }^{2}$ Suharnoko, Hukum Perjanjian Teori Dan Analisa Kasus (Prenadamedia Group 2004).[64-65].

3 Agus Yudha Hernoko, Hukum Perjanjian: Asas Proporsionalitas Dalam Kontrak Komersial (Prenadamedia Group 2014).[109].

${ }^{4}$ Sentosa Sembiring, Hukum Kepailitan Dan Peraturan Perundang-Undangan Yang Terkait Dengan Kepailitan (Nuansa Aulia 2006).[14]. 
rata parte. ${ }^{5}$ Para pihak yang dapat dikecualikan menurut undang-undang salah satunya adalah karena memiliki jaminan khusus. Jaminan khusus merupakan suatu persiapan yang dipersiapkan untuk menghadapi kemungkinan terburuk di kemudian hari. ${ }^{6}$

Selain mengajukan gugatan pailit terhadap debitor sebagai upaya dipenuhinya janji debitor, para kreditor juga dapat mengajukan gugatan diluar pailit, yaitu dengan gugatan lain-lain. Sesuai Pasal 3 ayat (1) Undang-Undang Nomor 37 Tahun 2004 tentang Kepailitan dan Penundaan Kewajiban Pembayaran Utang (selanjutnya disebut UU Kepailitan dan PKPU), terhadap putusan atas permohonan pernyataan pailit dan hal-hal lain yang berkaitan dan/atau diatur dalam UU Kepailitan dan PKPU, akan diputus oleh Pengadilan yang daerah hukumnya termpat kedudukan hukum debitor. Pihak ketiga yang merasa dirugikan karena barang milik debitor yang disita merupakan miliknya, dapat mengajukan derden verzet (perlawanan pihak ketiga) terhadap consevatoir beslag (sita jaminan) ${ }^{7}$

Pelaksanaan perjanjian sewa guna usaha dengan finance lease salah satunya dilakukan oleh PT. Orix Indonesia Finance dan PT. Tiara Utama Laundry. Kasus Posisi pada Putusan Nomor 355 K/Pdt.Sus-Pailit/2020 menerangkan bahwa PT. Orix Indonesia Finance yang dalam hal ini merupakan perusahaan pembiayaan selaku Penggugat sekaligus Kreditor dari PT. Tiara Utama Laundry mengajukan Gugatan Lain-Lain terhadap Octolin H. Hutagalung, S.H., M.H. selaku Kurator dari PT. Tiara Utama Laundry, atas objek sewa pembiayaan yang masih dikuasai oleh Kurator. Penguasaan itu terjadi akibat dari dikeluarkannya putusan pailit PT. Tiara Utama Laundry, sehingga PT. Tiara Utama Laundry demi hukum tidak memiliki hak dalam hal kepengurusan dan penguasaan harta kekayaan.

Berdasarkan contoh kasus antara PT. Orix Indonesia Finance dengan Octolin H. Hutagalung, S.H., M.H. selaku Kurator dari PT. Tiara Utama Laundry, maka

\footnotetext{
${ }^{5}$ ibid.

${ }^{6}$ Moch Isnaeni, Hipotek Pesawat Udara Di Indonesia (Dharma Muda 1996).[34].

${ }^{7}$ Yahya Harahap, Hukum Acara Perdata (Sinar Grafika 2008).[355-356].
} 
diperlukan analisis lebih lanjut mengenai akibat hukum perjanjian sewa guna usaha bilamana lessee dinyatakan pailit. Berkaitan dengan perjanjian sewa guna usaha tersebut, kedudukan objek perjanjian sewa guna usaha dalam kepailitan sewa guna usaha juga perlu penjelasan lebih lanjut.

\section{Metode Penelitian}

Penelitian ini termasuk dalam penelitian hukum (legal research) ${ }^{8}$ Penelitian hukum merupakan proses ilmiah untuk memecahkan isu hukum yang muncul dengan tujuan untuk memberikan pandangan atas isu hukum yang muncul. ${ }^{9}$ Sedangkan pendekatan yang dilakukan adalah dengan pendekatan perundangundangan (statute approach), pendekatan konsep (conceptual approach), dan pendekatan kasus (case approach). Rumusan masalah yang akan dianalisa adalah akibat hukum terhadap perjanjian sewa guna usaha dengan finance lease bilamana pihak lessee dinyatakan pailit serta objek perjanjian sewa guna usaha dengan finance lease termasuk dalam boedel pailit lessee.

\section{Karakteristik Perjanjian Sewa Guna Usaha}

Sewa guna usaha (leasing) sebagai salah satu bentuk perikatan di Indonesia, maka diharuskan tunduk pada undang-undang yang berlaku di Indonesia. Sedangkan untuk saat ini, hukum di Indonesia belum ada yang secara khusus mengatur mengenai sewa guna usaha. Oleh karenanya, diperlukan BW sebagai dasar hukum pengaturan sewa guna usaha. Sehingga, para pihak yang akan membuat perjanjian sewa guna usaha, memiliki dasar hukum untuk meminimalisir adanya kerugian serta memiliki kepastian hukum yang akan melindungi para pihak.

Perjanjian sewa guna usaha adalah salah satu bentuk perjanjian yang belum memiliki undang-undang yang mengatur secara khusus. Dengan demikian, perjanjian sewa guna usaha dikategorikan sebagai perjanjian tidak bernama (innominaat) yang lahir berdasarkan asas kebebasan berkontrak dan para pihak

\footnotetext{
${ }^{8}$ Peter Mahmud Marzuki, Penelitian Hukum: Edisi Revisi (Prenada Media 2017).[55].

${ }^{9}$ Peter Mahmud Marzuki, 'Penelitian Hukum' (2001) 16 Yuridika.[103].
} 
wajib tunduk pada perjanjian yang dibuat secara sah layaknya seperti undang-undang, sesuai yang tertera dalam Pasal 1338 ayat (1) BW.

Tidak diaturnya sewa guna usaha secara khusus dalam BW, tetapi tetap dapat diterapkan karena sifat Buku III BW yang menganut sistem terbuka (open system), maka diperbolehkan membuat perjanjian sesuai kesepakatan para pihak tersendiri. Sistem terbuka juga berarti bahwa para pihak diberikan kebebasan yang seluas-luasnya untuk mengadakan perjanjian yang berkaitan dengan isinya, dengan siapa saja, dan hal lain yang diperlukan, asalkan tidak melanggar hukum, ketertiban umum, dan kesusilaan. ${ }^{10}$

Kebebasan berkontrak yang menjadi dasar para pihak dalam membuat perjanjian didasarkan pada Pasal 1338 ayat (1) BW, berbunyi “Semua perjanjian yang dibuat secara sah berlaku sebagai undang-undang bagi mereka yang membuatnya". Kata "berlaku sebagai undang-undang bagi mereka yang membuatnya" mengindikasikan bahwa perjanjian yang telah dibuat tersebut akan mengikat para pihak dan oleh karenanya para pihak harus memenuhi isi perjanjian tersebut. ${ }^{11}$ Keberlakuan seperti undang-undang dikenal dengan asas pacta sunt servanda.

Kebebasan para pihak dalam membuat perjanjian sesuai Pasal 1338 ayat (1) BW juga mengindikasikan bahwa perjanjian tersebut hanya berlaku diantara para pihak yang membuatnya atau disebut juga asas privity of contract sesuai Pasal 1340 BW. Terhadap hak dan kewajiban, serta akibat hukum yang timbul apabila nantinya terjadi permasalahan akan hanya berdampak pada kedua belah pihak yang tertera dalam perjanjian. Asas privity of contract yang terdapat dalam perjanjian sewa guna usaha mengindikasikan bahwa lahir hak perorangan diantara para pihak. Hak perorangan adalah hak yang lahir diantara para pihak yang membuat perjanjian dan hanya dapat dipertahankan diantara para pihak tersebut. ${ }^{12}$

Bentuk kesepakatan yang telah tertuang dalam perjanjian sesuai dengan keinginan para pihak yang membuatnya akan menjadi aturan yang mengikat bagi pihak yang telah

\footnotetext{
${ }^{10}$ Subekti, Hukum Perjanjian (Intermasa 1998).[13].

${ }^{11}$ RED, 'Pelaksanaan Suatu Perjanjian' (Hukumonline, 2018) <https://m.hukumonline.com/berita/ baca/lt5a5c2fbdae8c4/pelaksanaan-suatu-perjanjian/> accessed 24 June 2021.

${ }^{12}$ Trisadini Prasastinah Usanti and et.al, Buku Ajar Hukum Perdata (Pusat Penerbitan dan Percetakan Unair (AUP) 2012).[50].
} 
menyepakati perjanjian. ${ }^{13}$ Keabsahan suatu perjanjian baik perjanjian bernama maupun perjanjian tidak bernama, tunduk pada Pasal 1320 BW. Dalam Pasal 1320 BW sebagai pasal yang berisi tentang syarat sah perjanjian, mengandung asas konsensualisme di dalamnya. Asas kebebasan berkontrak yang terdapat dalam Pasal 1338 ayat (1) BW tidak akan dapat dipisahkan dengan Pasal 1320 BW, yang mengandung asas konsesualisme. Konsekuensi dari adanya Pasal 1338 ayat (1) BW adalah bahwa perjanjian yang tidak sah, tidak akan memilihi daya mengikat terhadap para pihak yang terlibat dalam perjanjian.

Perikatan yang dibuat oleh para pihak harus memenuhi syarat sahnya sebuah perjanjian, agar terdapat payung hukum yang melindungi para pihak dalam melaksanakan perikatan. Syarat sah perjanjian tertuang dalam Pasal 1320 BW, dimana 4 (empat) syarat yang wajib dipenuhi adalah :

1. Sepakat mereka yang akan mengikatkan dirinya;

2. Kecakapan untuk membuat perikatan;

3. Suatu hal tertentu;

4. Suatu sebab yang diperbolehkan.

Perjanjian yang tidak memenuhi syarat hanya sebab yang diperbolehkan saja yang dapat membuat sahnya suatu perjanjian, tidak akan mendapat pengakuan oleh hukum, walaupun para pihak yang membuatnya mengakuinya. Apabila suatu saat ada pihak yang tidak mengakui dan berakhir dengan sengketa, maka hakim akan membatalkan atau menyatakan perjanjian batal. ${ }^{14}$

Persyaratan berupa sepakat bagi mereka yang mengikatkan dirinya dan kecakapan untuk membuat suatu perikatan termasuk dalam syarat subjektif, karena berkaitan dengan pribadi para pihak..$^{15}$ Terkait syarat suatu hal tertentu dan sebab yang halal merupakan syarat objektif, karena berkaitan objek perjanjian yang dilakukan. ${ }^{16}$ Suatu perjanjian yang tidak memenuhi syarat subjektif, maka perjanjian dapat dilakukan pembatalan, tetapi apabila perjanjian tidak memenuhi

\footnotetext{
${ }^{13}$ Yahman, Karakteristik Wanprestasi Dan Tindak Pidana Penipuan Yang Lahir Dari Hubungan Kontraktual (Prestasi Pustakarya 2011).[51].

${ }^{14}$ J Satrio, Hukum Perikatan, Perikatan Yang Lahir Dari Perjanjian (Citra Aditya Bakti 2001).[163].

${ }^{15}$ Subekti, Hukum Perjanjian (Intermasa 2002).[17].

16 ibid.
} 
syarat objektif, maka perjanjian akan batal demi hukum. ${ }^{17}$

Sepakat merupakan bentuk kesesuaian kehendak dengan memberikan persetujuan atau kesepakatan terkait hal-hal tertentu. ${ }^{18}$ Kehendak yang dimaksud disini adalah adanya keinginan para pihak untuk melakukan hubungan hukum. ${ }^{19}$ Terkait dengan kecakapan, setiap orang akan dianggap cakap kecuali oleh undang-undang dinyatakan tidak cakap, sesuai Pasal 1329 BW. Suatu hal tertentu yang dimaksud dalam Pasal 1320 BW adalah objek yang menjadi dasar perjanjian dilakukan, baik berupa benda, maupun sebuah prestasi yang harus dilakukan. ${ }^{20}$ Kausa yang diperbolehkan menerangkan tentang tujuan dibuatnya perjanjian. ${ }^{21}$

Sewa guna usaha sebagai salah satu bentuk perjanjian pembiayaan memiliki 2 (dua) macam jenis perjanjian, yakni sewa guna usaha dengan hak opsi (finance lease) dan sewa guna usaha tanpa hak opsi (operating lease). Hal tersebut sesuai dengan yang tertera dalam Pasal 2 ayat (1) Keputusan Menteri Keuangan Republik Indonesia Nomor 1169/KMK.01/1991, yaitu:

1. Kegiatan sewa guna usaha yang dilakukan dengan hak opsi (finance lease);

2. Kegiatan sewa guna usaha yang dilakukan tanpa hak opsi (operating lease).

Opsi atau finance lease sesuai Pasal 1 huruf o Keputusan Menteri Keuangan Republik Indonesia Nomor 1169/KMK.01/1991 adalah hak yang dimiliki oleh lessee untuk melakukan pembelian terhadap barang modal yang sebelumnya telah diperjanjikan dalam sewa guna usaha antara lessee dan lessor atau akan memperpanjang jangka waktu perjanjian. Finance Lease atau yang sering disebut dengan capital lease atau full-payout lease, memiliki beberapa ciri, diantaranya:22

1. Jangka waktu perjanjian yang relatif lebih lama;

2. Besarnya harga sewa dengan hak opsi harus dapat menutup harga barang modal dan keuntungan yang diharapkan oleh lessor;

${ }^{17}$ Diana Kusumasari, 'Pembatalan Perjanjian Yang Batal Demi Hukum' (Hukumonline, 2011) <https://m.hukumonline.com/klinik/detail/ulasan/cl4141/pembatalan-perjanjian> accessed 15 May 2021.

${ }^{18}$ Subekti, Bunga Rampai Ilmu Hukum (Alumni 2004).[4].

${ }^{19}$ J Satrio, Hukum Jaminan,Hak-Hak Jaminan Kebendaan (Citra Aditya Bakti 1993).[129].

${ }^{20}$ Abdul Kadir Muhammad, Hukum Perikatan (Citra Aditya Bakti 1990).[81-82].

${ }^{21}$ ibid.

${ }^{22}$ I Gusti Agung Wisudawan, 'Aspek Hukum Dalam Perjanjian Leasing (Sewa Guna Usaha)' (2014) 8 GaneÇ Swara.[66]. 
3. Diberi hak opsi untuk lessee yang berkeinginan untuk membeli barang modal yang telah disewakan diakhir perjanjian sewa guna usaha;

4. Sewa guna usaha dengan hak opsi dapat diberikan oleh perusahan pembiayaan;

5. Harga sewa perbulan yang dibayarkan oleh lessee dapat ditentukan dengan jumlah yang sama atau berbeda etergantung pada suku bunga pinjaman;

6. Biasanya lessee akan menanggung biaya pemelihataan, kerusakan, pajak, dan asuransi barang modal;

7. Kontrak perjanjian sewa guna usaha tidak dapat dibatalkan secara sepihak.

Dalam finance lease, lessee memiliki hak opsi terhadap barang modal pada saat berakhirnya perjanjian berdasarkan perhitungan nilai sisa (residual value), sedangkan pada operating lease barang modal akan dikembalikan kepada lessor ketika waktu perjanjian telah berakhir. ${ }^{23}$ Perjanjian sewa guna usaha dengan bentuk finance lease memiliki lebih banyak kerugian bagi leasee dibandingkan dengan bentuk perjanjian operational lease.

Selain dengan hak opsi, para pihak juga bisa melakukan perjanjian sewa guna usaha tanpa menggunakan hak opsi. Persyaratan yang harus dipenuhi agar perjanjian sewa guna usaha dapat dikategorikan tanpa menggunakan hak opsi terdapat dalam Pasal 4 Keputusan Menteri Keuangan Republik Indonesia Nomor 1169/KMK.01/1991:

1. Total pembayaran yang telah dibayarkan selama masa sewa guna usaha pertama ditambah dengan nilai sisa barang modal, tidak dapat memenuhi harga perolehan barang modal dan jumlah keuntungan lessor;

2. Dalam perjanjian sewa guna usaha tidak mencantumkan ketentuan hak opsi bagi lessee.

Operating Lease tidak mengandung perpindahan hak milik didalamnya. Pihak lessee hanya akan merasakan manfaat dari barang yang disewa dan setelah masa berlaku perjanjian selesai, barang wajib dikembalikan kepada lessor. Pelaksanaan operating lease memerlukan tenaga khusus terutama untuk melakukan pemeliharaan dan memasarkan kembali barang modal yang sebelumnya telah dilease-kan. ${ }^{24}$

\footnotetext{
${ }^{23}$ Sunaryo, Hukum Lembaga Pembiayaan (Sinar Grafika 2008).[54-55].

${ }^{24}$ Munir Fuady, Hukum Tentang Pembiayaan (Citra Aditya Bakti 2006).[19].
} 
Pranata hukum perjanjian yang berkembang dalam kehidupan masyarakat saat ini, baik berupa sewa guna usaha (leasing), sewa beli (hire purchase), dan jual beli angsuran didasarkan pada ketentuan hukum perdata diantaranya adalah "kebebasan berkontrak" sebagai asas pokok yang mendasari hukum perjanjian dan diatur dalam Pasal 1338 ayat (1) BW, serta asas konsesualisme yang diatur dalam Pasal $1320 \mathrm{BW}^{25}$

Sewa beli (Hire Purchase) adalah perjanjian yang dilakukan oleh penjual dan pembeli dengan cara memperhitungkan setiap pembayaran yang dilakukan pembeli hingga lunas sesuai dengan kesepakatan bersama, serta hak milik atas barang yang telah dibayar baru beralih dari penjual kepada pembeli setelah harga yang disepakati telah dilunasi oleh pembeli sesuai Pasal 1 huruf a Keputusan Menteri Perdagangan dan Koperasi Republik Indonesia Nomor 34/KP/II/80 tentang Perizinan Kegiatan Sewa Beli (Hire Purchase), Jual Beli Dengan Angsuran, dan Sewa (Renting).

Sistem ini memberikan penyelesaian dengan pembayaran angsuran dalam beberapa tahapan serta jangka waktu yang relatif lebih lama dibandingkan sistem pembayaran secara tunai. ${ }^{26}$ Barang yang telah disepakati akan diserahkan oleh penjual sewa kepada pembeli sewa saat perjanjian telah disepakati dan ditandatangani, akan tetapi peralihan hak milik atas barang baru berpindah dari penjual sewa kepada pembeli sewa, ketika pembayaran angsuran terakhir telah diterima oleh penjual sewa. ${ }^{27}$ Proses yang dilakukan dalam sewa beli sebenarnya lebih mendekati proses jual-beli dari pada sewa-menyewa, meskipun merupakan campuran dari kedua proses tersebut dan diberi judul "sewa-menyewa" ${ }^{28}$

Jika dalam sewa beli, lessee demi hukum secara otomatis akan menjadi pemilik barang di akhir waktu perjanjian, sedangkan dalam sewa guna usaha kepemilikan baru akan berpindah kepada lessee apabila hak opsi dilaksanakan

\footnotetext{
${ }^{25}$ Sri Gambir Melati Hatta, Beli Sewa Sebagai Perjanjian Tak Bernama: Pandangan Masyarakat Dan Sikap Mahkamah Agung Indonesia (Edisi Revisi) (Liberty 2015).[2].

${ }^{26}$ ibid.[1].

${ }^{27}$ Budi Rachmad, Multi Finance Handbook (Pradnya Paramita 2004).[60].

${ }^{28}$ Subekti, Aneka Perjanjian (Citra Aditya Bakti 2014).[54].
} 
oleh lessee. ${ }^{29}$ Sesuai dengan asas kebebasan berkontrak yang terdapat dalam Pasal 1338 ayat (1) BW jo. Pasal 1320 BW, sewa beli merupakan perkembangan dalam perjanjian jual- beli dan jenis dari jual beli angsuran. ${ }^{30}$

Jual beli angsuran adalah proses jual beli dimana para pihak dalam perjanjian telah sepakat untuk melakukan pembayaran secara angsuran terhadap barang yang telah diserahkan terlebih dahulu oleh penjual kepada pembeli, baik dalam hak milik maupun tidak dalam hak milik. ${ }^{31}$ Pengertian jual beli angsuran tersebut juga diperjelas dalam Pasal 1 huruf b Keputusan Menteri Perdagangan dan Koperasi Republik Indonesia Nomor 34/KP/II/80.

\section{Akibat Hukum Kepailitan Terhadap Perjanjian Sewa Guna Usaha}

Kepailitan merupakan Putusan Pengadilan yang mengakibatkan sita umum terhadap harta kekayaan debitor pailit, baik yang telah ada, maupun yang akan ada dikemudian hari. ${ }^{32}$ Secara umum, asas hukum kepailitan didasarkan pada Pasal 1131 BW, yang menjelaskan bahwa segala kebendaan pihak yang berutang, baik bergerak maupun tidak bergerak, baik yang sudah ada maupun yang akan ada di kemudian hari, akan menjadi tanggungan segala perikatan pihak tersebut. ${ }^{33}$ Sedangkan secara khusus, asas hukum kepailitan diatur dalam UU Kepailitan dan PKPU. ${ }^{34}$

Dalam Pasal 1 angka 1 UU Kepailitan dan PKPU, Kepailitan diartikan sebagai sita umum atas harta kekayaan debitor pailit yang hak pengurusan dan pemberesannya tidak lagi ada pada debitor, melainkan pada kurator dibawah pengawasan hakim pengawas. Suatu keadaan debitor dapat dikategorikan pailit apabila memenuhi syarat-syarat yang tertuang dalam Pasal 2 ayat (1) UU Kepailitan dan PKPU, yakni memiliki 2 (dua) atau lebih kreditor dan sedikitnya

${ }^{29}$ Alya Naomi Veralda Parapat, 'Hubungan Hukum Para Pihak Dalam Pembiayaan Kendaraan Bermotor Dengan Cara Leasing (Studi Kasus Pada PT. Mandiri Tunas Finance Jalan Adam Malik Medan)' (Universitas Sumatera Utara 2021).[42-43].

${ }^{30}$ Sri Gambir Melati Hatta, Op.Cit.[3].

${ }^{31}$ RM Suryodiningrat, Perikatan-Perikatan Bersumber Perjanjian (Tarsito 1980).[27]. 2008).[1].

${ }^{32}$ M Hadi Subhan, Prinsip, Norma, Dan Praktik Di Peradilan (Kencana Prenada Media Group

${ }_{33}$ Syamsudin Sinaga, Hukum Kepailitan Indonesia (Tatanusa 2012).[34].

34 ibid. 
ada 1 (satu) utang yang telah jatuh waktu dan dapat ditagih. Apabila telah terbukti secara secara sederhana ketentuan dalam Pasal 2 ayat (1) UU Kepailitan dan PKPU, maka Pengadilan Niaga harus mengabulkan pengajuan permohonan pailit tersebut, sesuai dengan Pasal 8 ayat (4) UU Kepailitan dan PKPU.

Selain itu, kepailitan merupakan penjabaran dari Pasal 1131 jo. Pasal 1132 BW, oleh karenanya: ${ }^{35}$

1. Kepailitan hanya meliputi harta debitor pailit dan bukan debitor secara perseorangan;

2. Debitor akan tetap memiliki kekayaan dan berhakatas kekayaan tersebut, hanya saja tidak lagi berhak untuk menguasai, menggunakannya, memindahkan, atau mengagunkannya;

3. Sitaan konservator secara umum akan meliputi seluruh harta pailit.

Dalam kepailitan, terdapat prinsip yang terkenal, yaitu prinsip paritas creditorium dan prinsip pari passu prorata parte. Prinsip tersebut berkaitan dengan jumlah utang yang dimiliki oleh debitor terhadap beberapa kreditor sehingga harta kekayaan yang dimiliki oleh kreditor nantinya akan dibagi secara proporsional kepada kreditor tersebut. ${ }^{36}$ Selain prinsip paritas creditorium dan prinsip pari passu prorata parte, salah satu prinsip penting yang ada dalam hukum kepailitan adalah prinsip structured creditors. Prinsip ini menglompokkan kreditor sesuai dengan kelasnya, yaitu: ${ }^{37}$

1. Kreditor separatis, adalah kreditor yang memiliki jaminan kebendaan;

2. Kreditor preferen, adalah kreditor yang menurut undang-undang pembayarannya harus didahulukan;

3. Kreditor konkuren, adalah kreditor yang tidak memiliki jaminan kebendaan dan tidak termasuk dalam pihak yang pembayarannya harus didahulukan menurut undang-undang.

\footnotetext{
${ }^{35}$ Kartini Muljadi, 'Actio Pauliana Dan Pokok-Pokok Tentang Pengadilan Niaga' in Rudhy A Lontoh (ed), Penyelesaian Utang Piutang Melalui Pailit atau Penundaan Kewajiban Pembayaran Utang (Alumni 2001).[300].

${ }^{36}$ M. Hadi Subhan, Op.Cit.[7].

37 ibid.[32-33].
} 
Perjanjian sewa guna usaha yang terbentuk dengan berdasar pada asas kebebasan berkontrak dalam Pasal 1338 ayat (1) BW dan asas konseualisme dalam Pasal 1320 BW menggambarkan adanya hubungan hukum terkait hukum kekayaan diantara kedua belah pihak. Perbuatan hukum yang dilakukan oleh pihak-pihak yang bersangkutan akan menimbulkan suatu hubungan hukum yang berbentuk hak dan kewajiban, dimana satu pihak akan memperoleh hak dari pihak lain yang sekaligus menjadi kewajiban pihak lain tersebut. ${ }^{38}$

Hak dan kewajiban tersebut akan mengikat lessee dan lessor selaku para pihak dalam perjanjian sewa guna usaha tanpa terkecuali. Salah satu hak dan kewajiban lesse adalah Memperoleh fasilitas pembiayaan dari lessor untuk membeli barang yang menjadi objek sewa guna usaha dan membayar angsuran sewa guna usaha setiap bulan sesuai jumlah dan waktu yang disepakati. ${ }^{39}$ Selain lessee, pihak lessor juga memiliki hak dan kewajiban yang wajib dilaksanakan dan dipenuhi, diantaranya menerima pembayaran cicilan uang barang modal sesuai dengan jumlah dan waktu yang telah disepakati serta memberikan pembiayaan pada lessee sesuai dengan yang diperjanjikan. ${ }^{40}$

Pihak lessee yang telah diputus pailit kemungkinan besar tidak bisa memenuhi segala kewajiban yang telah disepakati dengan lessor. Kewajiban yang belum selesai dipenuhi pelaksanaannya oleh lessee hingga pernyataan putusan pailit dikeluarkan adalah pembayaran angsuran yang belum diselesaikan hingga akhir. Terhentinya pembayaran angsuran yang telah disepakati mengakibatkan kerugian bagi lessor.

Sesuai Pasal 21 jo. Pasal 24 UU Kepailitan dan PKPU, putusnya pernyataan pailit kepada lessee akan meliputi seluruh harta kekayaan yang dimiliki pada saat putusan pailit diucapkan dan yang diperoleh selama proses kepailitan dan demi hukum akan kehilangan haknya dalam penguasaan dan pengurusan harta kekayaan yang termasuk dalam harta pailit. Debitor yang telah dinyatakan pailit hanya

${ }^{38}$ Subekti, Aspek-Aspek Hukum Perikatan Nasional (Alumni 1976).[12].

${ }^{39}$ Aprilianti Aprilianti, 'Perjanjian Sewa Guna Usaha Antara Lessee Dan Lessor' (2011) 5 Fiat Justisia: Jurnal Ilmu Hukum.[320].

${ }^{40} \mathrm{ibid.}$ 
berhak untuk melakukan perbuatan hukum yang dapat memberikan keuntungan atau menambah jumlah harta kekayaan untuk selanjutnya dimasukkan dalam boedel pailit. ${ }^{41}$

Berdasarkan Pasal 36 ayat (1) UU Kepailitan dan PKPU, apabila ketika putusan pernyataan pailit diucapkan masih terdapat perjanjian yang belum terlaksana atau baru sebagian terlaksana, pihak yang membuat perjanjian dengan debitor dapat meminta kepastian kepada kurator tentang kelanjutan pelaksanaan perjanjian sesuai dengan kesepakatan kurator dan kreditor tersebut. Jika kesepakatan terkait jangka waktu pelaksanaan perjanjian antara pihak yang membuat perjanjian dengan debitor dan kurator belum tercapai, maka hakim pengawas yang akan menetapkan jangka waktunya, sesuai Pasal 36 ayat (2) UU Kepailitan dan PKPU. Apabila selama jangka waktu yang ditentukan oleh hakim pengawas, kurator ternyata tidak memberikan jawaban atau tidak bersedia untuk melanjutkan perjanjian, maka perjanjian akan dianggap berakhir dan pihak yang membuat perjanjian dengan debitor dapat menuntut pembayaran ganti rugi dan akan diperlakukan sebagai kreditor konkuren menurut Pasal 36 ayat (3) UU Kepailitan dan PKPU.

\section{Ruang Lingkup Boedel Pailit}

BW sebagai dasar hukum yang mengatur mengenai hukum privat di Indonesia, mengatur tentang benda dalam Buku II BW setelah aturan mengenai orang sebagai subjek hukum terdapat dalam Buku I BW..$^{42}$ Merujuk pada Pasal 499 BW, benda yang dimaksud dalam hal ini tidak terbatas hanya pada benda yang berwujud barang (goed), namun juga mencangkup benda tidak berwujud yang berupa hak seseorang. ${ }^{43} \mathrm{Hal}$ ini mengindikasikan bahwa benda merupakan objek kepemilikan dan hak juga dapat menjadi objek kepemilikan, karena konsep

\footnotetext{
${ }^{41}$ Rifqani Nur Fauziah, 'Kepailitan Dan Akibat Kepailitan Terhadap Kewenangan Bidang Hukum Kekayaan' (DJKN, 2020) <https://www.djkn.kemenkeu.go.id/artikel/baca/13451/ Kepailitan-dan-Akibat-Kepailitan-Terhadap-Kewenangan-Debitur-Pailit-Dalam-Bidang-HukumKekayaan.html> accessed 22 July 2021.

${ }^{42}$ ibid.

${ }^{43}$ Trisadini Prasastinah Usanti, ‘Lahirnya Hak Kebendaan' (2012) 17 Perspektif.[45].
} 
hukum benda dalam BW adalah sesuatu yang dapat dilekatkan oleh kepemilikan. ${ }^{44}$ Benda dapat diklasifikasikan dalam beberapa jenis, yaitu: ${ }^{45}$

1. Benda berujud dan benda tidak berujud sesuai Pasal 503 BW;

2. Benda bergerak dan benda tidak bergerak sesuai Pasal 504 BW;

a. Benda bergerak adalah benda yang dapat dipindah dari satu tempat ke tempat yang lain. Benda bergerak dibedakan menjadi:

1) Benda bergerak karena sifatnya sesuai Pasal 509 BW;

2) Benda bergerak karena ketentuan undang-undang sesuai Pasal 511 BW.

b. Benda tidak bergerak adalah benda yang pada dasarnya tidak dapat dipindahkan dari satu tempat ke tempat lain, dibedakan menjadi:

1) Benda tidak bergerak menurut sifatnya, sesuai Pasal 506 BW;

2) Benda tidak bergerak karena tujuan pemakaiannya sesuai Pasal 507 BW;

3) Benda tidak bergerak karena memang demikian menurut undangundang sesuai Pasal 508 BW.

3. Benda habis pakai dan benda tidak habis pakai sesuai Pasal 505 BW.

Selain pembagian yang telah disebutkan sebelumnya, terdapat pembagian benda sesuai macamnya, yaitu: ${ }^{46}$

1. Bendayangdapatdiperdagangkandan bendayangtidakdapatdiperdagangkan sesuai Pasal 1332 BW.

2. Benda yang sudah ada dan benda yang baru akan ada dikemudian hari yang bersifat relatif dan bersifat mutlak sesuai Pasal 1131 BW jo. Pasal 1334 BW.

3. Benda yang dapat dibagi dan benda tidak dapat dibagi dalam Pasal 1160 BW jo. Pasal 1163 BW.

4. Benda yang dapat diganti dan benda yang tidak dapat diganti sesuai Pasal 1694 BW.

5. Benda bertuan dan benda tidak bertuan dalam Pasal 519 BW. ${ }^{47}$

Dalam hukum kepailitan, harta kekayaan debitor akan menjadi harta pailit sejak dikeluarkannya putusan pernyataan pailit dari Pengadilan Niaga, walaupun belum memiliki kekuatan hukum tetap. ${ }^{48}$ Setiap tindakan seseorang yang berkaitan

${ }^{44}$ Abdul Kadir Muhammad, Hukum Perdata Indonesia (Citra Aditya Bakti 2014).[128].

${ }^{45}$ Trisadini Prasastinah Usanti, et.al, Op.Cit.[40].

46 ibid.

${ }^{47}$ ibid.[22].

${ }^{48}$ Sutan Remy Sjahdeini, Hukum Kepailitan: Memahami Undang-Undang No. 37 Tahun 2004 Tentang Kepailitan (Grafiti 2012).[183]. 
dengan harta kekayaan akan menimbulkan akibat terhadap harta kekayaan yang dimiliki, baik akan membuat bertambahnya harta kekayaan (kredit) atau bahkan menimbulkan pengurangan harta kekayaan (debit). ${ }^{49}$

Pasal 21 UU Kepailitan dan PKPU merupakan pelaksana dari Pasal 1131 BW, dimana semua kebendaan debitor baik yang bergerak maupun tidak bergerak, baik yang sudah ada maupun yang sudah ada di kemudian hari, akan menjadi tanggungan dari setiap perikatan yang dilakukan. Pasal 1131 BW juga menegaskan harta kekayaan milik debitor yang termasuk dalam boedel pailit akan menjadi sita umum beserta dengan yang akan diperoleh selama kepailitan berlangsung. ${ }^{50}$

Berdasarkan ketentuan Pasal 21 UU Kepailitan dan PKPU, harta kekayaan debitor pailit yang termasuk dalam boedel pailit hanyalah harta milik debitor perorangan atau harta bersama apabila debitor telah kawin dan tidak melakukan perjanjian pisah harta. ${ }^{51}$ Apabila debitor pailit merupakan seorang pengurus suatu perseroan, maka harta pailit yang termasuk sita umum hanya harta pribadi debitor, tidak termasuk dengan harta perseroan. ${ }^{52}$

Terhadap kepailitan pada debitor yang telah kawin, apabila tidak terdapat perjanjian kawin yang dibuat, maka berlaku Pasal 64 ayat (1) UU Kepailitan dan PKPU, maka harta kekayaan akan dianggap sebagai persatuan harta. Hal ini juga berkaitan dengan Pasal 23 UU Kepailitan dan PKPU akibat adanya persatuan harta menjadi harta bersama serta berdasarkan Pasal 241 UU Kepailitan dan PKPU, harta debitor pailit juga mencakup aktiva dan pasiva.

Berbeda apabila debitor pailit membuat perjanjian kawin dengan pasangannya, maka akan terbentuk perpisahan harta antara harta bersama dan harta bawaan. Merujuk Pasal 62 ayat (1) UU Kepailitan dan PKPU apabila dalam suatu perkawinan yang terdapat perjanjian kawin salah satu pihak mengalami pailit, maka yang akan menjadi harta pailit hanyalah harta pihak yang mengalami pailit dan setelah dinyatakn pailit, maka semua keuntungan yang diperjanjikan

\footnotetext{
${ }^{49}$ M. Hadi Subhan, Op.Cit.[5].

50 ibid.[163].

${ }^{51}$ Elyta Ras Ginting, Hukum Kepailitan: Teori Kepailitan (Sinar Grafika 2018).[153].

52 ibid.
} 
berkaitan dengan harta pailit tidak dapat dituntut baik oleh pasangan debitor pailit maupun kreditor debitor pailit. ${ }^{53}$

Pasal 21 UU Kepailitan dan PKPU yang merupakan pasal pelaksana dari Pasal 1131 BW secara tidak langsung mengindikasikan bahwa benda yang dapat menjadi objek perjanjian sewa guna usaha diantaranya adalah benda bergerak maupun benda tidak bergerak, serta benda yang telah ada maupun benda yang akan ada di kemudian hari. Meski BW mengatur penggolongan benda sedemikian banyak, namun jenis penggolongan benda bergerak dan benda tidak bergerak yang memiliki konsekuensi lanjut terhadap sebuah perjanjian. ${ }^{54}$ Konsekuensi tersebut berkaitan erat dengan 4 (empat hal), yakni: ${ }^{55}$

1. Kedudukan berkuasa (bezit) Pasal 1977 BW;

2. Penyerahan (lavering) Pasal 612 BW;

3. Pembebanan (bezwaring) Pasal 1150 BW;

4. Daluwarsa (verjaring) Pasal 1977 ayat (1) BW.

Pentingnya pembagian benda bergerak dan benda tidak bergerak juga berpengaruh pada penggolongan harta apa saja yang dapat dimasukkan dalam boedel pailit. Hal tersebut untuk menjawab kapankan terjadinya perpindahan hak milik sehingga barang modal dapat dikategorikan sebagai harta kekayaan debitor pailit dan apakah debitor pailit adalah pihak yang memang berkuasa atau berhak atas barang tersebut.

\section{Kedudukan Objek Sewa Guna Usaha Dengan Finance Lease Jika Terjadi} Kepailitan Lessee

Dalam praktiknya, objek sewa guna usaha tidak terbatas hanya pada barang modal, melainkan barang konsumsi juga dapat dijadikan sebagai objek sewa guna usaha. ${ }^{56}$ Barang konsumsi merupakan barang yang digunakan untuk memenuhi

\footnotetext{
${ }^{53}$ ibid.[183].

${ }^{54}$ Moch Isnaeni, Hukum Benda Dalam Burgerlijk Wetboek (Revka Petra Medika 2016).[55-56].

${ }^{55}$ Frieda Husni Hasbullah, Hukum Kebendaan Perdata : Hak-Hak Yang Memberi Kenikmatan (IndHill-Co 2005).[45-48].

${ }^{56}$ Siti Amlikhatun Badriyah, 'Pemuliaan (Breeding) Asas-Asas Hukum Perjanjian Dalam Perjanjian Pembiayaan Dengan Objek Barang Modal Yang Berkembang Di Masyarakat (Studi Tentang Perjanjian Leasing Di Indonesia)' (Universitas Diponegoro 2011) 32.
} 
kebutuhan sehari-hari dan tidak digunakan untuk melakukan usaha. Salah satu barang konsumsi yang seringkali digunakan sebagai objek sewa guna usaha adalah sepeda motor dan mobil. Dimana barang tersebut termasuk dalam benda bergerak yang terdaftar. Sedangkan salah satu contoh barang modal adalah mesin cuci yang digunakan dalam usaha laundry, termasuk dalam benda bergerak.

Selama berlakunya perjanjian sewa guna usaha, maka hak milik atas barang modal tetap berada pada lessor. Pada Operating Lease, dilakukan proses menyewa suatu barang hanya untuk mendapatkan manfaat atas barang modal tersebut, sedangkan barang modal akan tetap menjadi hak milik lessor. ${ }^{57}$ Sedangkan apabila melakukan finance lease, hak milik barang modal awalnya berada dalam kepemilikan lessor, hak milik barang akan berpindah kepada lessee apabila dalam masa akhir perjanjian sewa guna usaha lessee telah menyelesaikan pembayaran angsuran, sedangkan apabila pembayaran angsuran tidak dilunasi oleh lessee, maka hak milik tetap berada pada lessor. ${ }^{58}$

Penggolongan barang modal pada kegiatan sewa guna usaha tersebut sebagai dasar perlakuan perpajakan yang berbeda antara sewa guna usaha dengan hak opsi dan sewa guna usaha tanpa hak opsi. ${ }^{59}$ Penggolongan barang modal yang terdapat dalam Pasal 3 huruf b Keputusan Menteri Keuangan Republik Indonesia Nomor 1169/KMK.01/1991 yang ditetapkan berdasarkan Pasal 11 UndangUndang No. 7 Tahun 1983 tentang Pajak Penghasilan. Pasal 3 huruf b Keputusan Menteri Keuangan Republik Indonesia Nomor 1169/KMK.01/1991 menerangkan tentang ciri barang modal dalam finance lease memiliki sifat kumulatif, dimana semua persyaratan tersebut harus dipenuhi. ${ }^{60}$

Sejak berlakunya Undang-Undang Nomor 10 Tahun 1994 tentang Perubahan Atas Undang-Undang Nomor 7 Tahun 1983 Tentang Pajak Penghasilan

${ }^{57}$ Denny G Omposunggu, Gregorius Adrian and Hanawati Vitaningtias, 'Perlindungan Hukum Bagi Lessee Terhadap Lessor Yang Melakukan Wanprestasi’ (2013) 1 Private Law.[19].

58 ibid.

59 'Kriteria Penggolongan Sewa Guna Usaha: Update-Kah?' (Pusdiklat Pajak, 2014) <https:// bppk.kemenkeu.go.id/content/berita/pusdiklat-pajak-kriteria-penggolongan-sewa-guna-usahaupdatekah-2019-11-05-d1c989d8/ > accessed 19 July 2021.

${ }^{60} \mathrm{ibid.}$ 
Sebagaimana Telah Diubah Dengan Undang-Undangnomor 7 Tahun 1991 (selanjutnya disebut UU Pajak Penghasilan), istilah "golongan" sudah tidak digunakan lagi dan diganti menjadi istilah "Kelompok". Penggunaan istilah "Kelompok" masih dipergunakan hingga berlakunya Undang-Undang No. 36 Tahun 2008 tentang Perubahan Keempat Atas Undang-Undang Nomor 7 Tahun 1983 Tentang Pajak Penghasilan.

Apabila ketika perjanjian telah berakhir dan lessee tidak menggunakan hak opsinya untuk melakukan pembelian barang modal atau perpanjangan masa sewa guna usaha, maka lessee diwajibkan untuk mengembalikan barang modal kepada lessor dengan biaya lessee, dalam keadaan baik dan dikembalikan ke tempat sesuai yang ditentukan oleh lessor.

\section{Analisis Putusan Nomor 355 K/Pdt.Sus-Pailit/2020}

Putusan Nomor 355 K/Pdt.Sus-Pailit/2020 merupakan putusan antara PT. Orix Indonesia Finance melawan Octolin H. Hutagalung, S.H., M.H., selaku kurator PT. Tiara Utama Laundry. Dalam perkara ini, PT. Orix Indonesia Finance mengajukan Gugatan Lain-Lain untuk meminta pengembalian objek sewa guna usaha berupa 10 unit washing machine yang saat gugatan dilayangkan objek tersebut termasuk dalam boedel pailit PT. Tiara Utama Laundry.

Hubungan hukum antara PT. Orix Indonesia Finance selaku perusahaan pembiayaan/lessor dan PT. Tiara Utama Laundry selaku penyewa guna usaha/lessee adalah para pihak yang telah bersepakat membuat perjanjian sewa guna usaha dengan hak opsi (finance lease). Ketika perjanjian masih berlangsung karena pembayaran angsuran belum terselesaikan dan jangka watu belum berakhir, PT. Tiara Utama Laundry dinyatakan pailit. Pernyataan putusan palit pada lessee mengakibatkan kedudukannya menjadi debitor pailit dan berakibat hukum demi hukum kehilangan haknya untuk menguasai dan mengurus harta kekayaan pailit sesuai Pasal 24 ayat (1) UU Kepailitan dan PKPU. Kewenangan pengurusan dan/atau pemberesan harta pailit akan menjadi kewenangan kurator yang dalam kasus ini adalah Octolin H. Hutagalung, S.H., M.H. Termasuk dengan pencatatan harta kekayaan kedalam boedel pailit. 
Lessor dalam hal ini menggugat kurator dengan dalih bahwa hak milik atas objek sewa guna usaha tersebut seharusnya masih berada di tangan lessor, dikarenakan pembayaran angsuran yang belum terselesaikan dan jangka waktu perjnjian yang belum berakhir. Dalam putusannya, hakim berpendapat bahwa oleh karena perjanjian sewa guna usaha terhadap mesin sebagai barang bergerak tidak dijamin dengan fidusia, maka perjanjian tersebut tergolong perjanjian biasa atau dibawah tangan. Serta majelis hakim juga berpendapat bahwa oleh karena pembayaran terhadap mesin laundry sebagian telah dilakukan pembayaran sewa oleh lessee maka objek sewa guna usaha tidak otomatis menjadi milik lessor tetapi menjadi harta pailit lessee dan lessor selaku kreditor dapat mengajukan tagihan kepada kurator terkait sisa tagihan

Pada gugatan ini, objek sewa guna usaha berupa 10 mesin cuci termasuk dalam kategori benda bergerak tidak atas nama. Benda bergerak memiliki titel yang sempurna dimana pihak yang menguasai dengan itikad baik akan dianggap sebagai pemiliknya sesuai Pasal 1977 BW. Meskipun, hak milik atas barang modal belum beralih dikarenakan pembayaran angsuran yang belum terselesaikan sesuai dengan jangka waktu yang telah disepakati dalam perjanjian sewa guna usaha. Akan tetapi, karena PT. Tiara Utama Laundry telah melakukan pembayaran angsuran selama beberapa kali dan benda secara nyata berada dalam penguasaannya, sesuai Pasal 1977 BW, maka pihak yang menguasai benda bergerak secara nyata akan dianggap sebagai pemilik benda dan oleh karenanya termasuk dalam harta kekayaan PT. Tiara Utama Laundry.

Objek sewa guna usaha dalam perjanjian yang berupa benda bergerak hanya perlu dilakukan penyerahan/lavering secara nyata sesuai Pasal 612 BW. Penyerahan objek beupa 10 mesin cuci yang secara nyata saat ini berada dalam penguasaan PT. Tiara Utama Laundry menandakan bawa PT. Orix Indonesia Finance juga telah menyerahkan secara yuridis objek tersebut.

Terhadap perjanjian sewa guna usaha dengan hak opsi antara PT. Orix Indonesia Finance dan PT. Tiara Utama Laundry merupakan perjanjian yang didasarkan pada asas kebebasan berkontrak pada Pasal 1338 ayat (1) BW. 
Pengaturan dalam Pasal 1338 ayat (1) BW juga mengindikasikan bahwa perjanjian yang dibuat berdasarkan kebebasan para pihak akan mengikat seperti undangundang bagi para pihak yang membuatnya. Kewajiban para pihak dalam perjanjian untuk mentaati isi perjanjian menandakan bahwa perjanjian hanya mengikat para pihak yang membuat perjanjian sesuai Pasal 1340 ayat (1) BW dan tidak dapat membawa kerugian kepada pihak lain yang tidak terdapat dalam perjanjian sesuai Pasal 1340 ayat (2) BW.

Asas privity of contract dan asas pacta sunt servanda yang terdapat dalam perjanjian antara PT. Orix Indonesia Finance dan PT. Tiara Utama Laundry menandakan bahwa hak yang lahir dalam perjanjian tersebut adalah hak perorangan dan oleh karenanya PT. Orix Indonesia Finance tidak berhak secara otomatis menjadi pemilik objek sewa guna usaha. Kepemilikan objek sewa guna usaha haruslah dinyatakan dengan hak kebendaan dan tidak bisa hanya dengan lahirnya hak perorangan antara PT. Orix Indonesia Finance dan PT. Tiara Utama Laundry menjadi bukti kepemilikan objek sewa guna usaha. Dengan demikian, tepat bahwa objek sewa guna usaha menjadi boedel pailit PT. Tiara Utama Laundry, karena tidak terdapat hak kebendaan diatasnya.

Terhadap perjanjian yang belum terselesaikan, lessor dapat menuntut kepastian kepada kurator tentang bagaimana kelanjutan perjanjian kepada kurator sesuai Pasal 36 ayat (1) UU Kepailitan dan PKPU. Apabila kurator tidak memberikan jawaban atau tidak bersedia untuk melanjutkan perjanjian, maka perjanjian berakhir dan PT. Orix Indonesia Finance selaku lessor dapat menuntut ganti kerugian dan akan berkedudukan sebagai kreditor konkuren sesuai Pasal 36 ayat (3) BW. Tetapi apabla kurator setuju untuk melanjutkan perjanjian, maka kurator wajib memberikan jaminan atas kesanggupannya sesuai Pasal 36 ayat (4) UU Kepailitan dan PKPU.

\section{Kesimpulan}

Perjanjian sewa guna usaha merupakan bentuk perjanjian yang lahir berdasarkan asas kebebasan berkontrak dalam Pasal 1338 ayat (1) BW. Kebebasan 
para pihak dalam membuat perjanjian tidak melepaskan kewajibannya untuk mematuhi perjanjian tersebut layaknya seperti undang-undang (asas pacta sunt servanda) serta hanya akan mengikat pada para pihak yang membuat perjanjian (asas privity of contract) sesuai Pasal 1340 BW. Oleh karenanya, lahirlah hak perorangan yang hanya bisa dipertahankan antar para pihak yang membuat perjanjian.

Terkait kepailitan lessee yang menggunakan perjanjian sewa guna usaha dengan hak opsi (finance lease), maka status barang modal adalah sebagai harta pailit. Berdasarkan UU Kepailitan dan PKPU, harta pailit meliputi seluruh harta kekayaan debitor pailit. Sesuai Pasal 21 UU Kepailitan dan PKPU yang merupakan pelaksana Pasal 1131 BW, baik terhadap benda bergerak maupun benda tidak bergerak, benda yang telah ada maupun benda yang akan ada. Dalam sewa guna usaha, pembayaran angsuran belum terselesaikan maka hak milik tetap berada di pihak lessor.

\section{Daftar Bacaan}

\section{Buku}

Fuady M, Hukum Tentang Pembiayaan (Citra Aditya Bakti 2006).

Ginting ER, Hukum Kepailitan: Teori Kepailitan (Sinar Grafika 2018).

Harahap Y, Hukum Acara Perdata (Sinar Grafika 2008).

Hasbullah FH, Hukum Kebendaan Perdata : Hak-Hak Yang Memberi Kenikmatan (IndHill-Co 2005).

Hatta SGM, Beli Sewa Sebagai Perjanjian Tak Bernama: Pandangan Masyarakat Dan Sikap Mahkamah Agung Indonesia (Edisi Revisi) (Liberty 2015).

Hernoko AY, Hukum Perjanjian: Asas Proporsionalitas Dalam Kontrak Komersial (Prenadamedia Group 2014).

Isnaeni M, Hipotek Pesawat Udara Di Indonesia (Dharma Muda 1996).

- - , Hukum Benda Dalam Burgerlijk Wetboek (Revka Petra Medika 2016).

Marzuki PM, Penelitian Hukum: Edisi Revisi (Prenada Media 2017). 
Muhammad AK, Hukum Perikatan (Citra Aditya Bakti 1990).

- - , Hukum Perdata Indonesia (Citra Aditya Bakti 2014).

Muljadi K, 'Actio Pauliana Dan Pokok-Pokok Tentang Pengadilan Niaga' in Rudhy A Lontoh (ed), Penyelesaian Utang Piutang Melalui Pailit atau Penundaan Kewajiban Pembayaran Utang (Alumni 2001).

Rachmad B, Multi Finance Handbook (Pradnya Paramita 2004).

Satrio J, Hukum Jaminan,Hak-Hak Jaminan Kebendaan (Citra Aditya Bakti 1993).

- - , Hukum Perikatan, Perikatan Yang Lahir Dari Perjanjian (Citra Aditya Bakti 2001).

Sembiring S, Hukum Kepailitan Dan Peraturan Perundang-Undangan Yang Terkait Dengan Kepailitan (Nuansa Aulia 2006).

Sinaga S, Hukum Kepailitan Indonesia (Tatanusa 2012).

Sjahdeini SR, Hukum Kepailitan: Memahami Undang-Undang No. 37 Tahun 2004 Tentang Kepailitan (Grafiti 2012).

Subekti, Aspek-Aspek Hukum Perikatan Nasional (Alumni 1976).

- - , Hukum Perjanjian (Intermasa 1998).

- - , Hukum Perjanjian (Intermasa 2002).

- - , Bunga Rampai Ilmu Hukum (Alumni 2004).

- -, Aneka Perjanjian (Citra Aditya Bakti 2014).

Subhan MH, Prinsip, Norma, Dan Praktik Di Peradilan (Kencana Prenada Media Group 2008).

Suharnoko, Hukum Perjanjian Teori Dan Analisa Kasus (Prenadamedia Group 2004). Sunaryo, Hukum Lembaga Pembiayaan (Sinar Grafika 2008).

Suryodiningrat RM, Perikatan-Perikatan Bersumber Perjanjian (Tarsito 1980).

Tunggal AW and Tunggal AD, Aspek Yuridis Dalam Leasing (Rineka Cipta 1994).

Usanti TP and et.al, Buku Ajar Hukum Perdata (Pusat Penerbitan dan Percetakan 
Unair (AUP) 2012).

Yahman, Karakteristik Wanprestasi Dan Tindak Pidana Penipuan Yang Lahir Dari Hubungan Kontraktual (Prestasi Pustakarya 2011).

\section{Jurnal}

Aprilianti A, 'Perjanjian Sewa Guna Usaha Antara Lessee Dan Lessor' (2011) 5 Fiat Justisia: Jurnal Ilmu Hukum.

Marzuki PM, ‘Penelitian Hukum' (2001) 16 Yuridika.

Omposunggu DG, Adrian G and Vitaningtias H, 'Perlindungan Hukum Bagi Lessee Terhadap Lessor Yang Melakukan Wanprestasi' (2013) 1 Private Law Usanti TP, ‘Lahirnya Hak Kebendaan' (2012) 17 Perspektif.

Wisudawan IGA, 'Aspek Hukum Dalam Perjanjian Leasing (Sewa Guna Usaha)' (2014) 8 GaneÇ Swara.

\section{Karya Ilmiah}

Badriyah SA, 'Pemuliaan (Breeding) Asas-Asas Hukum Perjanjian Dalam Perjanjian Pembiayaan Dengan Objek Barang Modal Yang Berkembang Di Masyarakat (Studi Tentang Perjanjian Leasing Di Indonesia)' (Universitas Diponegoro 2011).

Parapat ANV, 'Hubungan Hukum Para Pihak Dalam Pembiayaan Kendaraan Bermotor Dengan Cara Leasing (Studi Kasus Pada PT. Mandiri Tunas Finance Jalan Adam Malik Medan)' (Universitas Sumatera Utara 2021).

\section{Laman}

Fauziah RN, 'Kepailitan Dan Akibat Kepailitan Terhadap Kewenangan Bidang Hukum Kekayaan' (DJKN, 2020) <https://www.djkn.kemenkeu.go.id/ artikel/baca/13451/Kepailitan-dan-Akibat-Kepailitan-TerhadapKewenangan-Debitur-Pailit-Dalam-Bidang-Hukum-Kekayaan.html> accessed 22 July 2021.

'Kriteria Penggolongan Sewa Guna Usaha: Update-Kah?' (Pusdiklat Pajak, 2014) $<$ https://bppk.kemenkeu.go.id/content/berita/pusdiklat-pajak-kriteriapenggolongan-sewa-guna-usaha-updatekah-2019-11-05-d1c989d8/> accessed 19 July 2021.

Kusumasari D, 'Pembatalan Perjanjian Yang Batal Demi Hukum' (Hukumonline, 2011)<https://m.hukumonline.com/klinik/detail/ulasan/cl4141/ 
154 | Risma Cahya dan Hadi Shubhan: Kedudukan Objek Sewa...

pembatalan-perjanjian> accessed 15 May 2021.

RED, 'Pelaksanaan Suatu Perjanjian' (Hukumonline, 2018) <https://m. hukumonline.com/berita/baca/lt5a5c2fbdae8c4/ pelaksanaan-suatuperjanjian/> accessed 24 June 2021.

\section{Perundang-undangan}

Burgerlijk Wetboek voor Indonesie (Staatsblaad Nomor 23 Tahun 1847).

Undang-Undang Nomor 10 Tahun 1994 tentang Perubahan Atas Undang-Undang Nomor 7 Tahun 1983 Tentang Pajak Penghasilan Sebagaimana Telah Diubah Dengan Undang-Undangnomor 7 Tahun 1991 (Lembaran Negara Republik Indonesia Tahun 1994 Nomor 60, Tambahan Lembaran Negara Republik Indonesia Nomor 3567).

Undang-Undang Nomor 37 Tahun 2004 tentang Kepailitan dan Penundaan Kewajiban Pembayaran Utang (Lembaran Negara Republik Indonesia Tahun 2004 Nomor 131, Tambahan Lembaran Negara Republik indonesia Nomor 4443).

Peraturan Presiden Republik Indonesia Nomor 9 Tahun 2009 tentang Lembaga Pembiayaan.

Keputusan Menteri Perdagangan Dan Koperasi Republik Indonesia Nomor 34/ KP/II/80 Tahun 1980 tentang Perizinan Kegiatan Usaha Sewa Guna Usaha (Hire Purchase) Jual Beli Dengan Angsuran, dan Sewa (Renting) dicabut oleh Peraturan Menteri Perdagangan Republik Indonesia Nomor 21/M-Dag/ PER/10/2005 Tahun 2005 tentang Pencabutan Beberapa Perizinan Dan Pendaftaran di Bidang Perdagangan.

Keputusan Menteri Keuangan Republik Indonesia Nomor 1169/KMK.01/1991 Tentang Kegiatan Sewa Guna Usaha (Leasing).

Putusan Nomor 355 K/Pdt.Sus-Pailit/2020.

How to cite: Risma Cahya Yudita Pratama dan M. Hadi Shubhan, 'Kedudukan Objek Sewa Guna Usaha Dengan Hak Opsi (Finance Lease) Dalam Kepailitan Lessee’ (2022) Vol. 5 No. 1 Notaire. 